\title{
ANALISA KARAKTERISTIK MINYAK PLASTIK HASIL DUA KALI PROSES PIROLISIS
}

\author{
Untung Surya Dharma1), Dwi Irawan'2) \\ Jurusan Teknik Mesin Universitas Muhammadiyah Metro'12) \\ JI. Ki Hajar Dewantara No. 116 Iringmulyo Kota Metro ( 0725 ) 42445-42454 \\ Email : Untungsdh@yahoo.co.id
}

\begin{abstract}
Abstrak
Limbah plastik dapat dimanfaatkan sebagai bahan baku minyak plastik dengan menggunakan proses pirolisis. Minyak plastik yang dihasilkan dapat dimanfaatkan sebagai zat aditif atau campuran bahan bakar pada mesin. Pada Penelitian ini, proses pembuatan minyak plastik menggunakan dua kali proses pirolisis. Suhu reaktor pada proses pirolisis yang pertama dan kedua berbeda berturut-turut yaitu $200{ }^{\circ} \mathrm{C}$ dan $150{ }^{\circ} \mathrm{C}$. Dari hasil penelitian ini diketahui bahwa pada proses pirolisis pertama dengan suhu reaktor $200{ }^{\circ} \mathrm{C}$, dari $25 \mathrm{~kg}$ bahan baku menghasilkan 15,5 liter minyak plastik dalam waktu 80 jam. Sedangkan pada proses pirolisis kedua dengan suhu reaktor $150{ }^{\circ} \mathrm{C}$, dari 15 liter minyak plastik dari hasil proses pirolisis pertama menghasilkan 11,6 liter minyak plastik dalam waktu 3,33 Jam. Adapun karakter minyak plastik yang dihasilkan adalah massa jenis $771,4 \mathrm{~kg} / \mathrm{m}^{3}$, Viskositas $0,501 \mathrm{~m}^{2} / \mathrm{s}$ dan Nilai kalor $10518 \mathrm{~kJ} / \mathrm{kg}$
\end{abstract}

Kata kunci : Minyak Plastik, Proses Dua Kali Pirolisis, Karakteristik Minyak Plastik

\section{PENDAHULUAN}

Bahan bakar minyak plastik merupakan minyak sintetis yang terbuat dari senyawa hidrokarbon cair melalui proses pirolisis. Pirolisis minyak plastik adalah teknik pembakaran limbah plastik tanpa $\mathrm{O}_{2}$ dan dilakukan pada suhu tinggi. Produk utama dari pirolisis adalah senyawasenyawa hidrokarbon cair mulai dari $\mathrm{C}_{1}$ hingga $\mathrm{C}_{4}$ dan senyawa rantai panjang seperti parafin dan olefin [1]. Minyak plastik yang dihasilkan dapat digunakan sebagai zat additif atau campuran dalam bahan bakar. Keuntungan proses pirolisa adalah untuk menghasilkan bahan bakar minyak plastik dengan nilai kalor pembakaran yang baik.

Penelitian tentang minyak plastik sebagai bahan bakar alternatif telah banyak dilakukan dan hasilnya menunjukan bahwa minyak yang berasal dari limbah plastik ini sangat baik untuk dikembangkan karena selain mereduksi limbah plastik hingga $60 \%$ juga dapat menjadi sumber bahan bakar alternatif [2]. Dari penelitian lain bahkan menunjukan bahwa $75 \%$ limbah plastik dapat menghasilkan minyak plastik [3].

Adapun penelitian tentang sifat-sifat minyak plastik berbahan baku polietilina yang dibuat dengan menggunakan proses pirolisis ini diketahui bahwa densitas minyak yang dihasilkan adalah $939 \mathrm{~kg} / \mathrm{m}^{3}$ dan ignition point $30,4{ }^{\circ} \mathrm{C}$ sehingga lebih mudah dinyalakan.

Penelitian lain juga menunjukan bahwa proses pirolisis plastik sangat dipengaruhi temperatur yaitu kisaran $420{ }^{\circ} \mathrm{C}$ hingga $500{ }^{\circ} \mathrm{C}$ karena pada temperatur tersebut plastik baru dapat terdekomposisi [4], selain temperatur juga dipengaruhi oleh komposisi dan degradasi katalis [5].

Penelitian lebih lanjut tentang pembuatan minyak plastik dengan proses dua kali pirolisis dimana pada proses pirolisis yang pertama akan menggunakan temperatur $200{ }^{\circ} \mathrm{C}$ dan yang kedua $150{ }^{\circ} \mathrm{C}$ dari limbah plastik diharapkan dapat menghasilkan produk minyak plastik dengan kualitas yang baik namun diharapkan dapat mengefisienkan energi yang akan digunakan dalam proses pirolisis tersebut.

\section{TINJAUAN PUSTAKA \\ Bahan Bakar}

Bahan bakar adalah suatu bahan (Material) yang apabila dibakar akan menghasilkan energi panas. Setiap bahan bakar memiliki karakteristik dan nilai pembakaranyang berbeda-beda. Karakteristik inilah yang menentukan sifat-sifat dalam proses pembakaran [6 \& 7]. Sifat yang kurang menguntungkan dapat disempurnakan dengan jalan menambah bahan-bahan kimia kedalam bahan bakar tersebut. Sebagai contoh, batu bara nilai kalornya sangat bervariasi bergantung kandungan karbonnya. Dengan alasan tersebut, sekarang banyak metode yang digunakan untuk menaikkan nilaikalor bahan bakar dengan proses penambahan kandungan karbon ataudengan cara pengurangan unsur-unsur pengotornya. Untuk bahan bakar cair, khususnya bensin atau solar biasanya ditambahkan bahanbahan aditif dengan harapan akan mempengaruhi daya anti knocking atau daya letup dari bahan 
bakar, dan dalam hal ini menunjuk apa yang dinamakan dengan bilangan oktan (octane number) atau angka cetan pada solar (cetane number). Proses pembakaran bahan bakar dalam motor bensin atau mesin pembakaran dalam sangat di pengaruhi oleh bilangan tersebut $[8,9$, $10]$.

\section{Minyak Plastik}

Penggunaan plastik didalam kehidupan masyarakat sangat luas. Hal ini karena plastik memiliki banyak kelebihan dibandingkan bahan lainnya.Sebagian besar plastik yang digunakan masyarakat merupakan jenis plastik polietilena.Ada dua jenis polietilena, yaitu high density polyethylene (HDPE) danlow density polyethylene (LDPE).HDPE banyak digunakan sebagai botol plastik minuman, sedangkan LDPE untuk kantong plastik. Sehingga tidak mengherankan jika limbah plastik sangat banyak dan sulit untuk ditanggulangi, sehingga diharapkan limbah plastic ini dapat didaur ulang menjadi bahan yang lebih bermanfaat.

Salah satu perusahaan di Indonesia yaitu PT. Artha Teknindo - Artech [11] mengatakan bahwa limbah plastik dapat menjadi BBM. Dalam mengolah limbah plastik menjadi BBM, limbah plastik tidak diperlukan perlakuan pre-sortir dan tidak pula diperlukan kondisi yang harus bersih dari kotoran seperti pasir, abu, kaca, logam, tekstil, air, minyak bekas dan lain-lain. Setiap satuan berat plastik, dapat menghasilkan $70 \%$ Minyak, 16\% Gas, 6\% Carbon Solid dan 8\% Air. Adapun karakteristik dari minyak plastic yaitu antara lain massa jenis $0,73 \mathrm{~kg} / \mathrm{L}$ dengan nilai kalor sebesar $10498 \mathrm{~kJ} / \mathrm{kg}$. Menurut penelitian Joko Santoso [12], 2010, masa jenis minyak plastik dengan suhu reaktor pada antara $350{ }^{\circ} \mathrm{C}$ sampai $450{ }^{\circ} \mathrm{C}$, menghasilkan massa jenis ratarata sebesar $0,74 \mathrm{~kg} / \mathrm{L}$, viskositas $0,51 \mathrm{~m}^{2} / \mathrm{s}$ dan nilai kalor sebesar 43,33 MJ/kg.

\section{Karakteritik Minyak Plastik}

Karakteristik minyak plastik yang akan dibahas dalam penelitian ini hanya tiga parameter, yaitu massa jenis, viskositas dan nilai kalor.

\section{a. Massa Jenis Minyak Plastik}

Massa jenis diukur manual yaitu dengan cara menimbang dengan volume tertentu, dengan menggunakan persamaan berikut :

$$
\rho=\frac{m}{V}
$$

Keterangan :

$\rho$ : Massa jenis $(\mathrm{kg} / \mathrm{l})$

$m$ : Massa minyak $(\mathrm{kg})$

$V$ : Volume (liter)

\section{b. Viskositas}

Fluida yang mengalir melalui sebuah pipa dapat dipandang terdiri atas lapisan-lapisan tipis zat alir yang bergerak dengan laju berbeda-beda sebagai akibat adanya gaya kohesi maupun adhesi. Gesekan internal di dalam fluidadinyatakan dengan besaran viskositas atau kekentalan dengan satuan poise.Viskositas dapat diketahui dengan membandingkan satu fluida yaitu minyak hasil pirolisis dengan fluida lain yaitu air, dengan persamaan berikut:

Dimana :

$$
v_{x}=\frac{t_{x} \rho_{x}}{t_{a} \rho_{a}} v_{a}
$$

$$
\begin{aligned}
& v_{x}=\text { viskositas minyak }\left(\mathrm{m}^{2} / \mathrm{s}\right) \\
& t_{x}=\text { waktu alir minyak }(\mathrm{s}) \\
& \rho_{x}=\text { massa jenis minyak }\left(\frac{\mathrm{kg}}{\mathrm{m}^{3}}\right) \\
& t_{a}=\text { waktu alir air }(\mathrm{s}) \\
& \rho_{a}=\text { massa jenis air }\left(\frac{\mathrm{kg}}{\mathrm{m}^{3}}\right) \\
& v_{a}=\text { viskositas air }\left(\mathrm{m}^{2} / \mathrm{s}\right)
\end{aligned}
$$

\section{c. Nilai Kalor Bahan Bakar Minyak Plastik}

Nilai kalor bahan bakar dapat diketahui dengan menggunakan kalorimeter, dengan persamaan sebagai berikut :

Keterangan :

$$
Q_{s}=Q_{w}+Q_{c}
$$

$Q_{s}:$ Energi panas (Kalori)

$Q_{w}$ : Energi panas yang diserap oleh air (Kalori)

$Q_{c}$ : Energi panas yang diserap oleh kalorimeter (Kalori)

\section{TUJUAN PENELITIAN}

Tujuan dari penelitian ini adalah mengetahui karakteristik minyak plastik yang dihasilkandari limbah plastikmenggunakan proses pembuatan dengan cara dua kali proses pirolisis.

Adapun manfaat dari penelitian ini adalah sebagai dasar untuk penelitian-penelitian lebih lanjut baik tentang metode dalam menghasilkan minyak plastik dari limbah plastik maupun penggunaannya sebagai bahan bakar minyak, sehingga minyak plastik dapat menjadi salah satu sumber energi baru yang bersih dan ekonomis.

\section{METODE PENELITIAN \\ Tahapan Penelitian}

Adapun metode yang digunakan dalam penelitian ini adalah metode eksperimental, 
dengan tahapan-tahapan penelitian adalah sebagai berikut:

\section{a. Tahap Persiapan}

Tahapan persiapan meliputi pembuatan alat pirolisis dan penyediaan bahan baku yaitu limbah plastik jenis LDPE (kantong plastik bekas) dan jenis HDPE (botol plastik kemasan bekas).

\section{b. Tahap Pembuatan Minyak Plastik}

Metode yang digunakan dalam pembuatan minyak plastik adalah dengan metode dua kali proses pirolisis. Pada proses pirolisis pertama, suhu reactor yang digunakan adalah $200{ }^{\circ} \mathrm{C}$. Dengan bahan baku limbah plastik berupa kantong plastic bekas dan botol plastic kemasan bekas (campuran jenis LDPE dan HDPE) sebanyak $5 \mathrm{~kg}$ selama 16 jam. Setelah didapat minyak dari proses pertama kemudian dilanjutkan dengan proses pirolisis kedua.

Pada proses pirolisis yang kedua, suhu reactor yang digunakan adalah $150{ }^{\circ} \mathrm{C}$, bahan baku minyak plastic hasil pirolisis pertama sebanyak $3000 \mathrm{ml}$ yang diproses selama 40 menit.

\section{c. Tahap Pengujian Minyak Plastik}

Pengujian minyak plastik yang dihasilkan dilakukan untuk mengetahui karakteristik dari minyak itu sendiri dengan parameter yaitu massa jenis, viskositas dan nilai kalor.

\section{d. TahapAnalisa Data dan Kesimpulan}

Setelaha pengujian akan dilakukan analisa data yang didapat dan ditarik kesimpulan.

\section{Prosedur Pembuatan Minyak Plastik}

Prosedur pembuatan minyak plastik adalah sebagai berikut :

1. Cacah plastik bekas LDPE (kantong plastik bekas) dan jenis HDPE (botol plastik kemasan bekas) kemudian cuci bersih dan keringkan untuk mempermudah proses pirolisis.

2. Masukan cacahan limbah plastik kedalam alat pirolisis sebanyak $5 \mathrm{~kg}$ untuk proses pirolisis pertama selama 960 menit atau 16 jam

3. Jaga suhu didalam alat pirolisis konstan pada suhu $200{ }^{0} \mathrm{C}$ untuk mendapatkan minyak plastik yang berwarna kuning gelap.

4. Minyak plastik yang didapat dalam proses pirolis pertama ini selanjutnya dipanaskan kembali kedalam alat pirolis untuk proses pirolisis yang kedua.

5. Jaga suhu didalam alat pirolisis konstan pada suhu $150{ }^{0} \mathrm{C}$ selama 40 menit untuk mendapatkan minyak plastik dengan dua kali proses pirolisis yang warnanya kuning terang.

6. Lanjutkan secara berulang (5 kali) untuk mendapatkan nilai rata-rata dari data-data yang yang dibutuhkan.

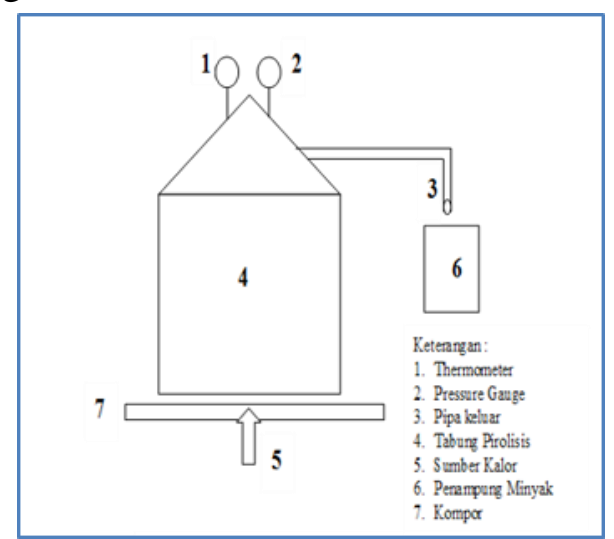

Gambar 1. Skema Alat Pirolisi

\section{HASIL DAN PEMBAHASAN \\ Data Hasil Penelitian}

Tabel 1. Hasil Pembuatan Minyak Plastik pada Proses Pirolisis Pertama

\begin{tabular}{|c|ccccc}
$\begin{array}{c}\text { Pengujian } \\
\text { Hari } \\
\mathrm{Ke}\end{array}$ & $\begin{array}{c}\text { Bahan Baku } \\
\text { Minyak }\end{array}$ & $\begin{array}{c}\text { Massa } \\
\text { Plastik } \\
(\mathrm{kg})\end{array}$ & $\begin{array}{c}\text { Suhu Proses } \\
\text { Pirolisis }\left({ }^{\circ} \mathrm{C}\right)\end{array}$ & $\begin{array}{c}\text { Waktu } \\
(\text { menit) }\end{array}$ & $\begin{array}{c}\text { Hasil } \\
\text { Pengujian } \\
(\mathrm{ml})\end{array}$ \\
\hline 1 & Limbah Plastik & 5 & 200 & 960 & 3100 \\
\hline 2 & Limbah Plastik & 5 & 200 & 960 & 3000 \\
\hline 3 & Limbah Plastik & 5 & 200 & 960 & 3200 \\
\hline 4 & Limbah Plastik & 5 & 200 & 960 & 3000 \\
\hline 5 & Limbah Plastik & 5 & 200 & 960 & 3200 \\
\hline & JMLAH & 25 & & 4800 & 15500 \\
\hline
\end{tabular}

Tabel 2. Hasil Pembuatan Minyak Plastik pada Proses Pirolisis Kedua

\begin{tabular}{|c|ccccc}
\hline $\begin{array}{c}\text { Pengujian } \\
\text { Hari } \\
\mathrm{Ke}\end{array}$ & $\begin{array}{c}\text { Bahan Baku } \\
\text { Minyak }\end{array}$ & $\begin{array}{c}\text { Volume } \\
\text { Minyak } \\
(\mathrm{ml})\end{array}$ & $\begin{array}{c}\text { Suhu Proses } \\
\text { Pirolisis } \\
\left({ }^{\circ} \mathrm{C}\right)\end{array}$ & $\begin{array}{c}\text { Waktu } \\
(\mathrm{m} \text { enit) }\end{array}$ & $\begin{array}{c}\text { Hasil } \\
\text { Pengujian } \\
(\mathrm{ml})\end{array}$ \\
\hline 1 & Lim bah Plastik & 3000 & 150 & 40 & 1920 \\
\hline 2 & Lim bah Plastik & 3000 & 150 & 40 & 1960 \\
\hline 3 & Lim bah Plastik & 3000 & 150 & 40 & 1900 \\
\hline 4 & Lim bah Plastik & 3000 & 150 & 40 & 1935 \\
5 & Lim bah Plastik & 3000 & 150 & 40 & 1920 \\
\hline & JMLAH & 15000 & & 200 & 11555 \\
\hline
\end{tabular}

\section{PEMBAHASAN}

\section{Hasil Pembuatan Minyak Plastik}

Sebelum dilakukan proses pirolisis, Bahan baku limbah plastikyang akan digunakan harus dicuci bersih terlebih dahulu hingga bersih agar terbebas dari kotoran. Proses pencucian ini dilakukan lebih kurang tiga kali dengan air yang mengalir. Setelah itu dilanjutkan dengan proses pencacahan untuk mempermudah pada saat proses pirolis dilakukan. Proses pembuatan minyak plastik dalam penelitian ini dilakukan dengan proses pirolisis sebanyak dua kali, dengan tujuan memaksimalkan kemurnian hasil minyak plastik. 
Pada hari pertama pembuatan minyak plastic, untuk proses pirolisis pertama, suhu proses pirolis yang digunakan adalah $200{ }^{\circ} \mathrm{C}$, dimana dengan bahan baku $5 \mathrm{~kg}$ limbah plastik didapat $3100 \mathrm{ml}$ minyak plastik dalam waktu 16 jam atau 960 menit. Kemudian dilanjutkan dengan proses pirolisi yang kedua, dengan menggunakan suhu $150{ }^{\circ} \mathrm{C}$, dalam waktu 40 menit didapat minyak plastik sebanyak $1920 \mathrm{ml}$.

Tabel 1 dan 2adalah table data hasil pembuatan minyak plastik berbahan baku limbah plastik yang merupakan campuran dari plastik jenis LDPE dan HDPE yang berupa kantong plastik bekas dan botol plastik kemasan bekas pada proses pirolisis pertama dan kedua.

\section{Karakteristik Minyak Plastik}

Adapun parameter dari karakter minyak plastik yang dihasilkan akan dilihat dari tiga parameter yaitu massa jenis, viskositas dan nilai kalor yang dikandung oleh minyak plastik.

\section{a. Massa Jenis Minyak Plastik}

Untuk mengetahui massa jenis minyak plastik yang dihasilkan dari proses pirolisis, dilakukan dengan cara memasukan minyak kedalam gelas ukur sebanyak $10 \mathrm{ml}$ kemudian menimbang massa minyak pada timbangan digital. Pengukuran ini dilakukan masing-masing sebanyak 5 kali, kemudian dilakukan perhitungandengan menggunakan rumus sebagaiberikut :

Dimana :

$$
\rho=\frac{m}{V}
$$

Maka :

$$
\begin{array}{ll}
\mathrm{m} & =7,65 \mathrm{gr} \\
\mathrm{V} & =10 \mathrm{ml}
\end{array}
$$

$$
\begin{aligned}
& \rho=\frac{7,65 \mathrm{gr}}{10 \mathrm{ml}} \\
& \rho=0,765 \mathrm{gr} / \mathrm{ml}
\end{aligned}
$$

Pada Tabel 3 Berikut akan menyajikan tentang hasil perhitungan massa jenis dari minyak yang dihasilkan.

Tabel 3. Massa Jenis Minyak Plastik Pada Proses Pirolisis Kedua

\begin{tabular}{|cc|cc|c|}
\hline $\begin{array}{c}\text { Pengujian } \\
\text { No: }\end{array}$ & Bahan B aku & $\begin{array}{c}\text { Massa Minyak } \\
(\mathrm{gr})\end{array}$ & $\begin{array}{c}\text { Volume Ninyak } \\
(\mathrm{ml})\end{array}$ & $\begin{array}{c}\text { Massa Jenis } \\
(\mathrm{kg} \mathrm{L})\end{array}$ \\
\hline 1 & Limbah Plastik & 7,65 & 10 & 0,765 \\
\hline 2 & Limbah Plastik & 7,70 & 10 & 0,770 \\
\hline 3 & Limbah Plastik & 7,74 & 10 & 0,774 \\
\hline 4 & Limbah Plastik & 7,78 & 10 & 0,778 \\
\hline 5 & Limbah Plastik & 7,70 & 10 & 0,770 \\
\hline & Nilai Rata-rata & 7,714 & 10 & 0,7714 \\
\hline
\end{tabular}

Dari Tabel 3 diatas dapat diketahui bahwa massa jenis minyak plastik dengan dua kali proses pirolis adalah sebesar $0,7714 \mathrm{~kg} / \mathrm{L}$ atau setara dengan $771,4 \mathrm{~kg} / \mathrm{m}^{3}$. Nilai yang dihasilkan ini tidak berbeda jauh dengan penelitian terdahulu yang telah dilakukan oleh Joko Santoso, 2010, yaitu pembuatan minyak plastik berbahan baku plastic jenis LDPE dengan suhu proses pirolisis $450{ }^{\circ} \mathrm{C}$ didapat $0,77 \mathrm{~kg} / \mathrm{L}$. Artinya proses dua kali pirolisis ini cukup baik digunakan apabila sumber kalor untuk menghasilkan suhu diatas $400{ }^{\circ} \mathrm{C}$ tidak terpenuhi.

\section{b. Viskositas Minyak Plastik}

Viskositas minyak plastik dalam penelitian ini dengan cara membandingkan dengan viskositas air, dengan rumus sebagai berikut :

$$
v_{x}=\frac{t_{x} \rho_{x}}{t_{a} \rho_{a}} v_{a}
$$

Diketahui:

$$
\begin{aligned}
t_{x} & =5 \mathrm{~s} \\
\rho_{x} & =771,4 \frac{\mathrm{kg}}{\mathrm{m}^{3}} \\
t_{a} & =6,22 \mathrm{~s} \\
\rho_{a} & =995,7 \frac{\mathrm{kg}}{\mathrm{m}^{3}} \\
v_{a} & =0,801 \mathrm{~m}^{2} / \mathrm{s}
\end{aligned}
$$

Maka :

$$
\begin{aligned}
& \eta_{x}=\frac{5,1 \mathrm{~s} \times 771,4 \mathrm{~kg} / \mathrm{m}^{3}}{6,22 \mathrm{~s} \times 995,7 \mathrm{~kg} / \mathrm{m}^{3}} 0,801 \mathrm{~m}^{2} / \mathrm{s} \\
& \eta_{x}=0,51 \mathrm{~m}^{2} / \mathrm{s}
\end{aligned}
$$

Dari rumus diatas, diketahui bahwa pada massa jenis $995,7 \mathrm{~kg} / \mathrm{m}^{3}$ maka waktu alir air adalah sebesar 6,22 detik dengan viskositas air sebesar $0,801 \mathrm{~m}^{2} / \mathrm{s}$. Sehingga untuk menghitung viskositas maka dibutuhkan pengujian untuk mengetahui waktu alir minyak plastik. Tabel hasil perhitungan dari hasil pengujian waktu alir minyak plastik dapat dilihat seperti pada Tabel 4 di bawah ini.

Tabel 4. Data Hasil Viskositas Minyak Plastik yang dihasilkan

\begin{tabular}{|c|c|c|}
\hline $\begin{array}{c}\text { Pengujian } \\
\text { ke }\end{array}$ & $\begin{array}{c}\text { Waktu Alir } \\
\text { Minyak } \\
(\mathrm{s})\end{array}$ & $\begin{array}{c}\text { Viskositas } \\
\text { Minyak } \\
\left(\mathrm{m}^{2} / \mathrm{s}\right)\end{array}$ \\
\hline 1 & 5,1 & 0,509 \\
\hline 2 & 5,0 & 0,499 \\
\hline 3 & 5,0 & 0,499 \\
\hline 4 & 4,9 & 0,488 \\
\hline 5 & 5,1 & 0,509 \\
\hline Nilai Rata-rata & 5,02 & 0,501 \\
\hline
\end{tabular}

Dari Tabel 4 diatas diketahui bahwa viskositas minyak plastik yang dihasilkan dalam penelitian ini adalah sebesar $0,501 \mathrm{~m}^{2} / \mathrm{s}$. Nilai ini juga mendekati nilai rata-rata viskositas minyak 
plastik yang telah diteliti oleh Joko Santoso, 2010 yaitu $0,51 \mathrm{~m}^{2} / \mathrm{s}$.

\section{c. Nilai kalor Minyak Plastik}

Pengujian nilai kalor dari minyak plastik yang dihasilkan dalam penelitian ini diketahui seperti pada Tabel 5 dibawah ini.

Tabel 5. Data Hasil Pengujian kalor Minyak Plastik

\begin{tabular}{c|c|c|}
\hline $\begin{array}{c}\text { Sampel } \\
\text { No: }\end{array}$ & Bahan Sampel & $\begin{array}{c}\text { Nilai Kalor } \\
(\mathrm{kJ} / \mathrm{kg})\end{array}$ \\
\hline 1 & Minyak Plastik & 10518 \\
\hline 2 & Minyak Plastik & 10516 \\
\hline 3 & Minyak Plastik & 10516 \\
\hline 4 & Minyak Plastik & 10520 \\
\hline 5 & Minyak Plastik & 10518 \\
\hline Nilai Rata-rata & & 10517,6 \\
\hline
\end{tabular}

Dari Tabel 5 diatas didapatkan nilai kalor dari minyak plastik yang di proses dengan cara dua kali proses pirolisis memiliki nilai kalor sebesar $10517,6 \mathrm{~kJ} / \mathrm{kg}$ atau dibulatkan menjadi 10518 $\mathrm{kJ} / \mathrm{kg}$.Hasil ini tidak berbeda jauh dengan hasil minyak plastik untuk bahan bakar yang telah dipublikasikan oleh PT. Artha Teknindo Artech, 2013 yaitu sebesar 10498 kJ/kg.

\section{KESIMPULAN DAN SARAN \\ Kesimpulan}

Dari penelitian awal yang telah dilakukan disimpulkan bahwa:

1. Pada proses pirolisis pertamadengan suhu 200 ${ }^{\circ} \mathrm{C}$, dari $25 \mathrm{~kg}$ bahan baku menghasilkan 15,5 liter minyak plastik dalam waktu 80 jam.

2. Pada proses pirolisis kedua dengan suhu 150 ${ }^{\circ} \mathrm{C}$, dari 15 liter minyak plastik dari hasil proses pirolisis pertama menghasilkan 11,6 liter minyak plastik dalam waktu 3,33 Jam.

3. Massa jenis minyak plastik yang dihasilkan adalah $771,4 \mathrm{~kg} / \mathrm{m}^{3}$.

4. Viskositas minyak plastik yang dihasilkan adalah $0,501 \mathrm{~m}^{2} / \mathrm{s}$

5. Nilai kalor dari minyak plastik yang dihasilkan sebesar $10518 \mathrm{~kJ} / \mathrm{kg}$

6. Dengan didapatkannya karakter minyak plastik yang dihasilkan diketahui bahwa minyak plastik ini layak untuk dijadikan campuran bahan bakar, sehingga penelitian dapat dilanjutkan ketahap pengaplikasian minyak plastik sebagai campuran bahan bakar premium.

\section{Saran}

Dari hasil penelitian tentang pembuatan minyak plastik ini, menunjukan bahwa minyak plastik dapat digunakan sebagai bahan bakar bagi mesin motor, sehingga kelanjutan penelitian ini dalam mengaplikasikan minyak plastik untuk campuran bahan bakar premium layak untuk dilanjutkan.

\section{DAFTAR PUSTAKA}

[1] Rahyani Ermawati, 2011, Konversi Limbah Plastik Sebagai Sumber Energi Alternatif, Jurnal Riset Industri, Vol. V, No.3.

[2] Miller, S.J. Shah, N. Hufman, G.P., 2005, Conversion of waste plastic to lubricant base oil, American Chemical Society, 19 (4) : $1580-1586$

[3] Purwanti Ani, Sumarni, 2008, Kinetika Reaksi Pirolisis Plastik Low Density polyethylene (LDPE), AKPRIND. Yogyakarta.

[4] Caglar, A., Aydinli, B. 2009, Isothermal CoPyrolisis of Hazelnut Shell and Ultra High Molecular Weight polyethylene : The effect of Temperature and composition on the amount of pyrolisis product, Journal of analytical and applied pyrolisis, vol. $86: 304$ $-309$.

[5] Sakata, Y., Uddin, M.A., Muto, A., Narazaki, K., Murata, K., Kaji, M., 1996, Thermal and Catalytic Degradation of municipal waste plastic into fuel oil, Polym Recyccling, 2 (4), 309.

[6] Cengel, Yunus A. 2005. Thermodynamic. Fifthh edition, E-book.

[7] Culp, Archie W. Sitompul, Darwin. 1996. Prinsip-prinsip konversi energi, Penerbit Airlangga.

[8] Kuo, K. Kenneth, 2005, Principles of Combustion, second edition, John Wiley \& Son, inc, USA.

[9] Turns, Stephen R. 2000, An Introduction to Combustion, second edition, Mc.GrawHill, USA.

[10]Arismunandar,wiranto.(1980). Penggerak Mula Motor Bakar Torak.Bandung : ITB.

[11]PT. Artha teknindo - artech, Mengolah Limbah Plastik Menjadi Energi.www.artech.co.id , bekasi. Akses tanggal 22 juni 2014.

[12]Santoso, Joko, 2010, Uji Sifat minyak plastic Pirolisis dan Uji Perormasi Kompor Berbahan Bakar Minyak Pirolisis dari Sampah Plastik. 